Article

\title{
'Greening' Green Infrastructure. Good Italian Practices for Enhancing Green Infrastructure through the Common Agricultural Policy
}

\author{
Stefano Magaudda ${ }^{1, *}$, Romina D'Ascanio ${ }^{2}$, Serena Muccitelli ${ }^{3}$ and Anna Laura Palazzo ${ }^{2}$ (D) \\ 1 DICEA, Department of Civil and Environmental Engineering, Sapienza University of Rome, \\ 00184 Rome, Italy \\ 2 Department of Architecture, Roma Tre University, 00184 Rome, Italy; romina.dascanio@uniroma3.it (R.D.A.); \\ annalaura.palazzo@uniroma3.it (A.L.P.) \\ 3 Department of City and Regional Planning, Cornell University in Rome, 00184 Rome, Italy; \\ sm2522@cornell.edu \\ * Correspondence: stefano.magaudda@uniroma1.it
}

Received: 12 January 2020; Accepted: 11 March 2020; Published: 16 March 2020

check for updates

\begin{abstract}
The Common Agricultural Policy (CAP) was established by the European Community in the 1950s to provide financial support to farmers in member states, increase agricultural productivity by promoting technical progress, and ensure a fair standard of living for farmers. Over time; awareness about the externalities of intensive farming would prompt environmentally friendly practices. These include, in the current programming period 2014-2020, the so-called "greening", which consists of: (i) crop diversification; (ii) the maintenance of permanent grassland surfaces; and (iii) the availability of $5 \%$ of arable land for ecological focus areas devoted to agricultural practices beneficial for the climate and the environment. These provisions, spurred by a decades-long debate that also stresses the importance of creating/restoring ecological connectivity on different scales to counter land fragmentation, are in tune with spatial planning initiatives throughout Europe. Here the point is how to combine these directions with either "ecological networks" (EN), designed as physical corridors to be preserved and enhanced for plants and animals' mobility needs; or "green infrastructure" (GI), defined on the European level as a "strategically planned network of natural and semi-natural areas with other environmental features designed and managed to deliver a wide range of ecosystem services" (European Commission; 2013). While in several European countries environmental measures targeting farmers and ecological networks directed at specific areas have been merged in a place-based approach, Italy is lagging behind. In general, no guidelines have been provided on the national level to support regional paths, while regions and municipalities lack the resources to implement GI. Conversely, while greening policies in the framework of the CAP are properly funded, they lack directions to be efficiently allocated. Against the backdrop of such concerns, this paper frames and reflects upon ongoing practices in three pilot areas in different Italian regions, selected based on desk analysis, in-depth interviews, and direct knowledge. Here, despite or thanks to the legislative framework, experimental approaches have been adopted to harness performance issues in targeted areas through broad participation by public and private stakeholders and multilevel governance schemes, opening possible pathways in view of the forthcoming programming period.
\end{abstract}

Keywords: common agricultural policy; green infrastructure; greening; ecological networks; regional planning; multi-level governance 


\section{Introduction}

On the European level, there is broad agreement about the need to integrate environmental issues related to biodiversity and ecological continuity with other sectoral policies within a territorial framework in order to strengthen their effectiveness. Until recently, agriculture and environmental policies have followed separate, often conflicting paths [1-4].

From the turn of the century onward, increasingly demanding agri-environmental measures and greening obligations under the Common Agricultural Policy (CAP) have been conveyed into different national legal frameworks. Several experiences in various European countries have been harnessing the "greening" tool provided by the 2014-2020 programming period in areas devoted to ecological networks and more generally to environmental continuity. Regional planning tools have been supportive in addressing a wide range of "open space" features and types ranging from ecological networks (EN) to green infrastructure (GI). GI has recently been defined by the homonymous European strategy as "strategically planned network of natural and semi-natural areas with other environmental features designed and managed to deliver a wide range of ecosystem services," which are in turn defined "as the direct and indirect contributions of ecosystems to human well-being" [5-7]. This statement, encompassing the production of food and water, the control of climate and disease, nutrient cycles and oxygen production, and spiritual and recreational benefits among ecosystem services [8], turns to GI for sustainable development issues on various scales, allowing multi-level governance models while accommodating land-use provisions and requirements [9].

This article investigates possible correlations between greening measures and GI in some Italian contexts, mainly within regional legal frameworks and bottom-up governance schemes tied to agri-environmental policies [10]. In fact, the Italian case stands out for its delay in embedding such principles within a place-based strategy. In terms of multilevel governance, the problem is twofold. On the one hand, regional and local planning tools entrusted with environmental measures and lately with green infrastructure display critical overlap; on the other hand, according to long lasting tradition, sectoral approaches falling under different administrative jurisdictions prevail over comprehensiveness [11]. Other crucial issues relate to poor commitment to joint initiatives; farmers, local communities and elected officials do not engage in paths of cooperation, apart from a few instances [12].

The paper is structured as follows: Section 2-General overview-compares the particular point of view of European institutions after a decades-long debate fed by fundamental contributions from research and civil society. The current "state of the art" in the case of Italy fails to fulfill specific targets either within the CAP or within environmental policies.

Section 3-Materials and methods-relies on desk analysis, in-depth interviews, and direct participation in ongoing European projects to identify three study cases in Italy that differ in location, size, and type of agreements, yet align with the need to encompass environmental issues in the CAP 2014-2020 programming period.

Section 4-Results-investigates several outcomes, assessing and synthesizing mutual interactions, awareness raising, and capacity building in the selected areas to overcome rigid sectoral schemes among local authorities, practitioners, and local communities.

Section 5-Discussion and Conclusions-highlights crucial issues, both in terms of current vertical subsidiarity with top-down practices and horizontal subsidiarity by means of public-private partnership arrangements. A major critical aspect in these teams concerns their sustainability over time for the implementation and management of green infrastructure. Some recurring approaches have also been detected, allowing for innovative institutional, social, and financial perspectives with an eye on future CAP reform.

Ultimately, the essential issues for reshaping integrated sustainability agendas, coupling functional performance related to ecological networks and ecosystem services with design requirements and layouts for their best allocation (conformance criteria), draw upon area-based strategies and strong coordination among the different stakeholders. 


\section{General Overview}

This article begins with a study of policy measures and tools promoted on the European level related to agriculture and the environment and eventually transcribed as commitments within the legislative and programming framework of member states.

The EU is currently encouraging integration between agriculture and the environment. On the one hand, the CAP has been enlarging its scope to also encompass environmental and biodiversity objectives, from boosting farming practices to maintaining grassland habitats in permanent pastures, protecting water and habitats through ecological focus areas (EFA), and diversifying crops. On the other hand, the European Biodiversity Strategy awaits implementation through national regulatory frameworks and planning initiatives that are capable of programming and managing ecological continuity and green infrastructure [13].

With reference to the Italian case, this section summarizes the evolution of a decades-long debate by European institutions regarding the treatment of environmental issues within the framework of the CAP (Section 2.1) and environmental issues, up to the formulation of the Green Infrastructure Strategy, which makes it possible to bridge the gap between measures addressing similar purposes (Section 2.2).

In fact, despite both environmental conditionality, which supports farmers in exchange for environmentally friendly practices, and the mandatory implementation of ecological continuity, practical applications are failing to frame greening policies within ecological connectivity.

\subsection{Enhancing Conditionality within the Common Agricultural Policy}

In Italy, an impassable barrier has long existed between environmental and agricultural issues. Some important driving forces in this regard have undoubtedly been the CAP's slow, steady, and self-reliant path, strong resistance from the agri-food sector to sustainable innovations in production and productivity horizons, and, last but not least, difficulties in connecting spatial planning-conferred on regions and municipalities - to beneficial environmental practices, bypassing local authorities [14].

For over 60 years, the CAP has played a crucial role in building Europe. Launched in 1958 at the Stresa Conference, it long remained unique within the portfolio of EU policies [15,16]. A series of adjustments and variations to ensure environmental values for agricultural activities gave rise to an autonomous reflection within the European institutions amid the backdrop of tangible concerns about the need to politically justify continuity in public support of a sector that was losing workers in both percentages and real terms.

CAP was originally intended to support agriculture income according to strong market protectionism and price support measures rather than to assist local communities with new facilities. The scope was to provide general funding for modernization in the six founding members (France, Germany, Italy, Belgium, The Netherlands, and Luxembourg). In this framework, food production was secured against the risk of supply shortage, even acting as a remarkable factor of cohesion [17].

In the mid-eighties, once the objective of food safety was achieved, agricultural policy would disclose a deep conflict between two opposing sides: supporters of a radical reform for the development of rural areas on the one hand, and on the other, defenders of the status quo intolerant of any innovation. In 1987, the Single European Act was enforced, stating that "action by the Community relating to the environment shall have the following objectives: (i) to preserve, protect, and improve the quality of the environment; (ii) to contribute towards protecting human health; and (iii) to ensure a prudent and rational utilization of natural resources" [18].

The Delors Plan, "Bringing the Single Act to success: a new frontier for Europe", at the launch of the structural policy, paved the way for relevant changes, since it argued that "rural development must not only be a collateral problem for agricultural market policy, but a legitimate goal with full rights" $[19,20]$. This statement was coupled with policies addressing the production and reproduction of environmental values regardless of the beneficiaries' condition as "farmers practicing farming as their main occupation". Since then, agri-environmental measures have been designed to encourage farmers to protect and enhance the environment on their farmland by providing payments in return for 
services such as good farming practices, encompassing forestry, tourism, craft activities, environmental protection, and conservation of natural areas.

At the turn of the century, the CAP would address increasingly ambitious issues such as: less intensive production methods in order to reduce environmental impacts; chemical emission reductions; organic farming; carbon retention; landscape care and the protection of natural resources; and public access to natural areas for recreational purposes [21].

Along with current direct support for farmers (Pillar I), rural development would be fostered by a specific budget heading (Pillar II) allowing for spatial allocation of expenditures within Rural Development Programmes (RDPs) designed to promote innovative paths after long-standing experience carried out with the special programs leader on a local basis [22,23] (Table 1).

Table 1. Main steps of the CAP from 2000 onwards (prepared by the authors).

\begin{tabular}{|c|c|c|}
\hline $\begin{array}{l}\text { Programming } \\
\text { Period }\end{array}$ & Reform & Main Contents Related to Environmental Issues \\
\hline $2000-2004$ & Agenda 2000 & $\begin{array}{l}\text { CAP reforms broke the link between direct payments and production. } \\
\text { More emphasis was placed on the environment and animal welfare. } \\
\text { - } \\
\text { "Decoupling": breaking the link between direct payments to farmers } \\
\text { - } \quad \text { "Cross-compliance": farmers receive subsidies in the form of a single } \\
\text { payment in return for keeping the land in good agricultural and } \\
\text { ecological conditions, and fulfilling food safety, environmental, animal } \\
\text { health, and welfare standards. }\end{array}$ \\
\hline $\begin{array}{l}2005-2009 \\
2010-2013\end{array}$ & $\begin{array}{l}\text { Fischler Reform } \\
\text { Health Check }\end{array}$ & $\begin{array}{l}\text { Rural development plays an increasing role in setting CAP strategies, aligning } \\
\text { with the EU's structural policy. }\end{array}$ \\
\hline 2014-2020 & Europa 2020 & $\begin{array}{l}\text { The CAP budget is split into two headings (Pillar I and Pillar II) } \\
\text { Pillar I } \\
\text { Under the direct payment scheme, the greening payment is introduced as the } \\
\text { second most important component after the basic payment, for an amount } \\
\text { corresponding to } 30 \% \text { of the national ceiling, equal for all Member States. It is } \\
\text { paid annually per eligible hectare. } \\
\text { Farmers should comply with the following agricultural practices beneficial for } \\
\text { the climate and the environment: } \\
\text { - } \quad \text { crop diversification ( } 2 \text { arable crops for holdings between } 10 \text { and } 30 \\
\text { hectares, } 3 \text { arable crops for holdings exceeding } 30 \text { hectares); } \\
\text { - } \quad \text { maintaining permanent grassland surfaces; } \\
\text { the availability of } 5 \% \text { of the arable land for ecological focus areas } \\
\text { (commonly referred to as EFAs). } \\
\text { Pillar II } \\
\text { This accounts for } 28 \% \text { of the CAP budget, allowing for spatial allocation of } \\
\text { expenditure within Rural Development Programmes (RDPs). The measures } \\
\text { common to all regional programs are: } \\
\text { - } \\
\text { facilitating generational turnover; } \\
\text { - } \quad \text { manoting agri-environmental and climate-change-related measures; } \\
\text { - } \\
\text { - }\end{array}$ \\
\hline
\end{tabular}

In the current programming period (2014-2020), the CAP accounted for 38\% of the entire EU financial statement. In Italy, the budget devoted to RDPs, deemed to better support sustainable farming and innovation as well as boosting employment, increased by $18.5 \%$ at current prices compared to the programming period 2007-2013, while Pillar I decreased by 8.3\% [24].

Within Pillar I, the greening, which is the "green" component of the basic income support, was introduced in order to make the EU direct payment system more environmentally friendly and thus to obtain a "basic level of environmental management" from all beneficiaries.

Despite the expectations raised by greening as a tool to produce environmental public goods, their territorial allocation is a key problem in Italy. Greening measures have not significantly shaped the Italian context due to land ownership fragmentation and average size generally well below the 10-hectare threshold. 
In turn, Pillar II represents a missed opportunity for Italian regions. Other European nations with comparable levels of complexity such as France, Germany, and Spain, have used the National Framework, an overarching discipline containing elements common to all RDPs, to facilitate coordination between the regions. In Italy, 21 regional RDPs have been approved, as well as a national RDP addressing risk management, the protection of animal biodiversity, and the efficient use of water resources.

Merging the environmental and agricultural policies listed in Table 2 may serve as a practical framework to implement green infrastructure stemming from Pillar II of the CAP, targeting Priority 4-Restoring, conserving, and improving ecosystems that depend on agriculture and forestry-and Priority 5-Promoting the efficient use of resources and supporting progress towards a low-carbon economy that can adapt to climate change in the agricultural, food, and forestry sectors.

Table 2. Environmentally oriented measures within the 2014-2020 RDPs.

\begin{tabular}{|c|c|}
\hline Measures & Sub-Measures \\
\hline $\begin{array}{l}\text { Measure } 4 \text {-Investment in } \\
\text { physical assets }\end{array}$ & $\begin{array}{l}\text { 4.3 Aid for investment in infrastructures tied to developing, } \\
\text { modernizing, and adapting agriculture and forestry } \\
\text { 4.4 Aid for non-productive investment in meeting agricultural, } \\
\text { environmental, and climate targets }\end{array}$ \\
\hline $\begin{array}{l}\text { Measure 7-Basic services and } \\
\text { village renewal in rural areas }\end{array}$ & $\begin{array}{l}\text { 7.3 Aid for creating, improving, and expanding basic local } \\
\text { services for the rural population, including recreational and } \\
\text { cultural activities, and related infrastructure } \\
\text { 7.4 Aid for investment in recreational infrastructure for public } \\
\text { use, tourist information, and small-scale tourist infrastructure } \\
\text { 7.5 Aid for studies/investments tied to maintaining, reclaiming } \\
\text { and restoring the natural and cultural heritage of villages, rural } \\
\text { landscapes, and areas with a high natural value, including their } \\
\text { social and economic aspects, as well as ecological } \\
\text { awareness-raising initiatives }\end{array}$ \\
\hline $\begin{array}{l}\text { Measure } 10-\text { Agri-environment } \\
\text { and climate }\end{array}$ & $\begin{array}{l}\text { 10.1 Aid for agri-environmental and climate commitments } \\
\text { 10.2 Aid for the conservation, sustainable use, and development } \\
\text { of genetic resources in agriculture }\end{array}$ \\
\hline $\begin{array}{l}\text { Measure } 12-\text { Payments under } \\
\text { Natura } 2000 \text { and the Water } \\
\text { Framework Directive }\end{array}$ & $\begin{array}{l}\text { 12.1 Compensation payments for agricultural areas in the Natura } \\
2000 \text { Network } \\
\text { 12.2 Compensation payments for forestry areas in the Natura } \\
2000 \text { Network } \\
\text { 12.3 Compensation payments for agricultural areas included in } \\
\text { basin hydrological plans }\end{array}$ \\
\hline $\begin{array}{l}\text { Measure 15-Forestry, } \\
\text { environmental and climate } \\
\text { services and forest conservation }\end{array}$ & $\begin{array}{l}\text { 15.1 Payments for forestry, environmental, and climate } \\
\text { commitments }\end{array}$ \\
\hline Measure 16-Cooperation & $\begin{array}{l}\text { 16.2 Aid for pilot projects and developing new products, } \\
\text { practices. processes, and technologies } \\
\text { 16.5 Aid for joint actions performed to mitigate climate change } \\
\text { and adapt to it, and for joint approaches to environmental } \\
\text { projects and existing environmental practices }\end{array}$ \\
\hline
\end{tabular}

Furthermore, cooperation arrangements supported by measure 16 deemed capable of encouraging technical, organizational, and social innovation have been poorly financed or poorly practiced, missing the objective of prioritizing green networks beneficial for the climate and the environment $[25,26]$.

The CAP reform after 2020 is supposed to change the entire structure of the policy itself through three key elements. Firstly, it foresees the drafting of a single "CAP strategic plan" per Member State expected to mediate between the European policy and regional programming. Such national programming frames of reference will be based on the assessment of needs, targeting and performance monitoring to cover and ensure greater coherence between the two Pillars (direct payments to farmers 
and support for rural development) [27]. Indeed, the Commission has to approve the strategic plans when satisfied with their quality. As a consequence, each region will develop its own RDP according to the national strategic plan, which will have an operational character [28].

Secondly, a new system of "enhanced conditionality" is expected to streamline current mechanisms of cross-compliance and greening payments in tying income support (and other area- and animal-based payments) to environmentally and climate-friendly farming practices and standards defined as "Good Agricultural and Environmental Conditions" (GAECs) and "Statutory Management Requirements" (SMRs).

Thirdly, a complementary set of (voluntary) tools will be offered to farmers to help achieve the CAP environmental and climate objectives. 'Eco-schemes' represent a new stream of funding aiming at strengthening the ecological baseline. They are payment schemes for caring for the environment and climate that will be funded by member states under the CAP's direct payments. Member states (within state/regional conferences) will have to provide one or more eco-schemes, which will remain voluntary measures testing a reward beyond conditionality. The Commission clarifies that even though eco-schemes have features in common with support for agri-environment climate commitments available under Pillar I, there are significant differences between the two. In particular, eco-schemes offer the possibility to grant direct payments as an incentive to farmers adopting practices beneficial for the environment and the climate (going beyond the costs incurred or the income foregone due to the adoption of these practices) [27].

\subsection{From Ecological Networks to Green Infrastructure: An Attempt to Integrate Agriculture and the Environment}

Urbanization and urban sprawl pose a strong threat to natural and agricultural areas [29]. In the 1990s, European countries initiated planning and management processes addressing ecological networks according to the Habitats Directive complying with major international strategies for biodiversity [30-32]. Ecological networks, as tools for improving biodiversity and ecological connectivity among habitats, were designed to consider different levels of nature protection (Table 3).

Table 3. Components of Ecological Networks (prepared by the authors).

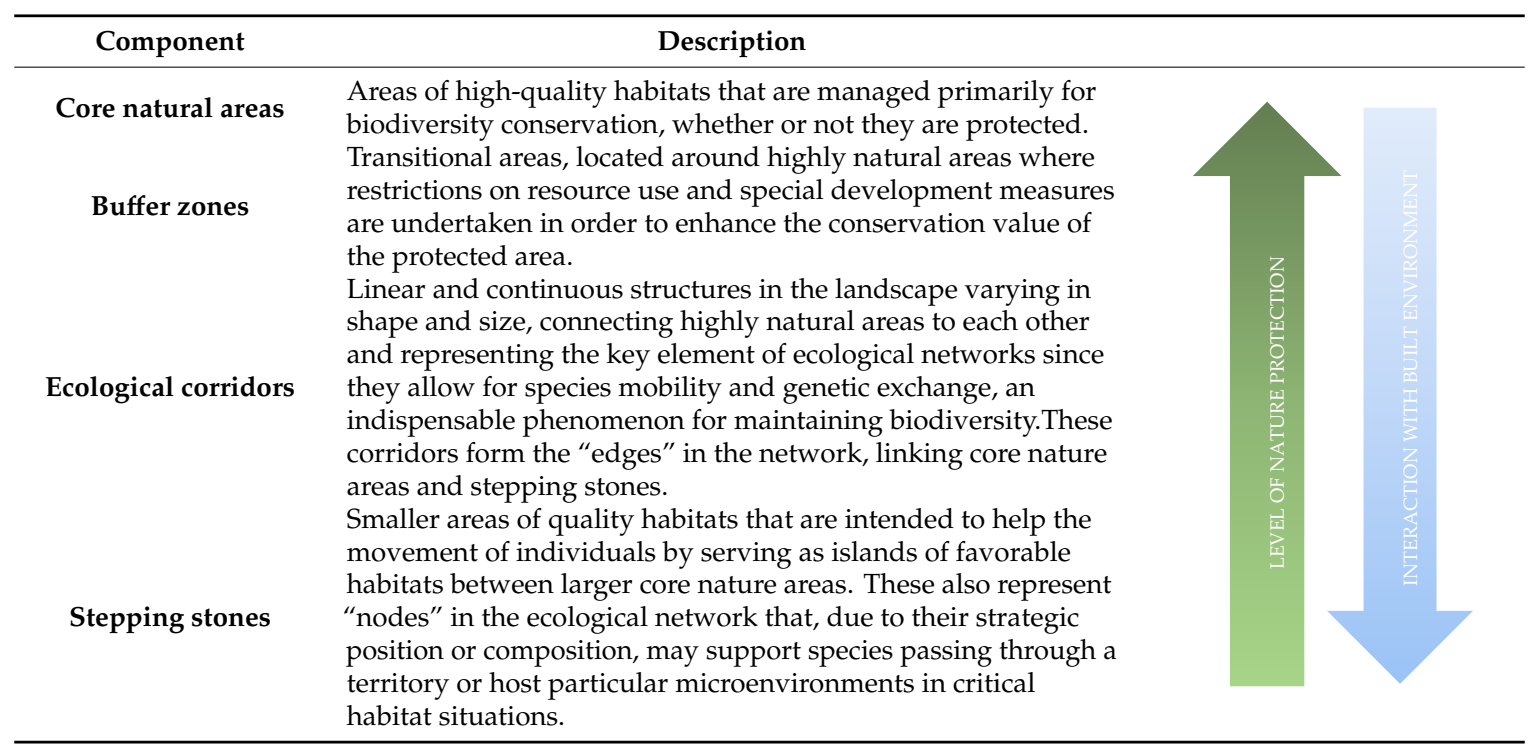

The aim of connecting open spaces with different degrees of naturalness has gradually been combined with the need to also enhance interactions in rural and peri-urban areas [33].

Starting in the early 2000s, eco-agricultural connections have been at the core of seminal debates among planners and policy makers highlighting the multiple benefits of ecological and natural systems for communities and economies. The key role of GI, somehow supplanting ecological networks due to 
more comprehensive targets in addressing environmental sustainability [34,35], leverages not only ecological functionality but also social, cultural and economic activities involving communities at large [36,37]. In France, the legislative framework sets the ground for regional and urban planning dealing with green infrastructure, merging ecological issues with the basic needs of human communities on different scales [38]. In Germany, cases of urban regeneration are associated with energy and climate challenges. In Italy, which lacks national-level directives to harness CAP measures and ecological connectivity/green infrastructure strategies, implementation follows different paths at different paces based on the specific case. Scant propensity to cooperate and a lack of funds for implementation and management referring to defective multi-level governance are delaying alignment with other countries.

In sum, GI delivers environmental (and social) advantages [39] regarding biodiversity and ecological restoration, adaptation, and mitigation measures to counter the manifold effects of pollution and climate change [40,41]. Furthermore, it lends itself to light, flexible policy frameworks addressing multilevel governance. Hansen and Pauleit have listed three main features: (i) strategic approach (GI planning aims for long-term benefits but remains flexible for changes over time); (ii) social inclusion (GI planning stands for communicational and socially inclusive planning and management); and (iii) trans-disciplinarity (GI planning is based on knowledge from different disciplines, such as: landscape ecology, urban and regional planning, and landscape architecture, and is developed in partnership with different local authorities and stakeholders) [42].

Two further perspectives- "landscape", maximizing perceptive, utility, and recreational value, and "ecosystem services", i.e., direct and indirect contributions of ecosystems to human well-being-feed both ecological networks and green infrastructure, requiring spatial planning to specify features, patterns, and uses (Figure 1), and coupling human and natural science as well as different budget headings.

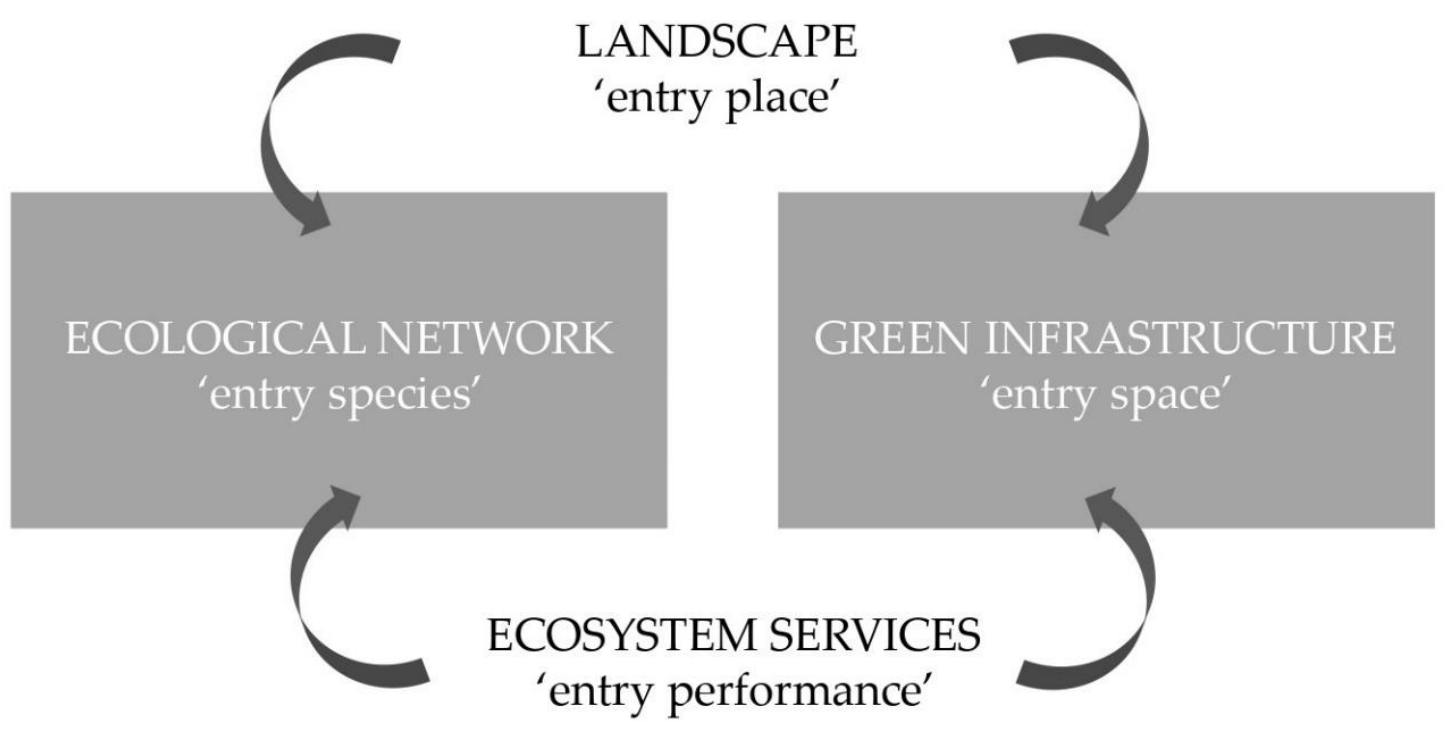

Figure 1. Ecological Networks and Green Infrastructure. The nexus of two paradigms. Coupling biodiversity (entry "species") with human activities (entry "space") may clarify and enable relationships among sectors, policies, and tools conventionally separated (prepared by the authors).

\section{Materials and Methods}

Without a national strategy integrating agricultural and environmental policies, the Italian case can be read as an array of independent approaches "in the field". In this framework, several particular aspects emerge in terms of:

- $\quad$ legislative references displaying an overlapping of competences and administrative sectors; 
- $\quad$ spatial constraints due to poor directions for green infrastructure implementation and weak support for accommodating agri-environmental measures within spatial planning;

- $\quad$ structural constraints such as land-use and land-tenure fragmentation, lack of cooperation between public and private stakeholders.

Considering the policy-oriented character of the processes being analyzed, a qualitative approach in the design of the study cases was selected and performed according to the seminal work of Bruno Dente and Francesco Kjellberg. A wide range of governance issues have been taken into account concerning both nature and function of rules dealing with structural arrangements, decision-making and financial aspects [43] (Table 4).

Table 4. Types of reforms in local governance, adapted by the authors from Dente and Kjellberg, p.11.

\begin{tabular}{|c|c|c|}
\hline Subject of Reforms & Intergovernmental Relationships & Internal Local Government \\
\hline 1. Organizations & $\begin{array}{l}1.1 \text { Structural } \\
\text { (i.e., change in number of Local Authorities, } \\
\text { administrative boundaries) }\end{array}$ & $\begin{array}{l}1.2 \text { Organizational } \\
\text { (i.e., changes in relations between political and } \\
\text { administrative bodies) }\end{array}$ \\
\hline 2. Decision-making & $\begin{array}{l}2.1 \text { Functional and procedural } \\
\text { (i.e changes in the Administrations' functions, } \\
\text { procedures) }\end{array}$ & $\begin{array}{c}2.2 \text { Local programming } \\
\text { (i.e, implementation/update of programming } \\
\text { tools, plans) }\end{array}$ \\
\hline 3. Financial resources & $\begin{array}{c}3.1 \text { Funding } \\
\text { (i.e., change in EU, national, regional funding) }\end{array}$ & $\begin{array}{c}3.2 \text { Local funding } \\
\text { (i.e., variation in fares regimes, local accounting } \\
\text { regulations) }\end{array}$ \\
\hline
\end{tabular}

It has to be noted that in the selected study cases, formal agreements among institutional bodies have been made possible with no changes in the administrative structure, while decision-making aspects as well as innovations related to the financial support take on greatest importance. It can be argued that place-specific governance reforms in the public domain have been able to prompt private partnerships by creating a milieu conducive to shared paths. First, ongoing experiences throughout the country were selected using desk analysis and interviews with administrators and professionals committed to environmental and agricultural issues. Subsequently, three study cases were selected in as many Italian regions (Piedmont, Marche, Lazio, Figure 2). The common features of these experiences, which differ in geographic condition, size, promoter, community engagement, and budget headings, are the following (Table 5).

- They are good practices where existing programming tools have been linked to CAP funding for the implementation and management of GI;

- They target contexts differing in terms of environmental, productive, social and regulatory features;

- They are part of regional programming and planning (such as the Environmental Regeneration Program, Provincial Territorial Plan, Regional Landscape Plan) with a specific focus on biodiversity conservation;

- They involve the agricultural sector stakeholders in the policy process development for the definition of objectives, strategies and interventions. 


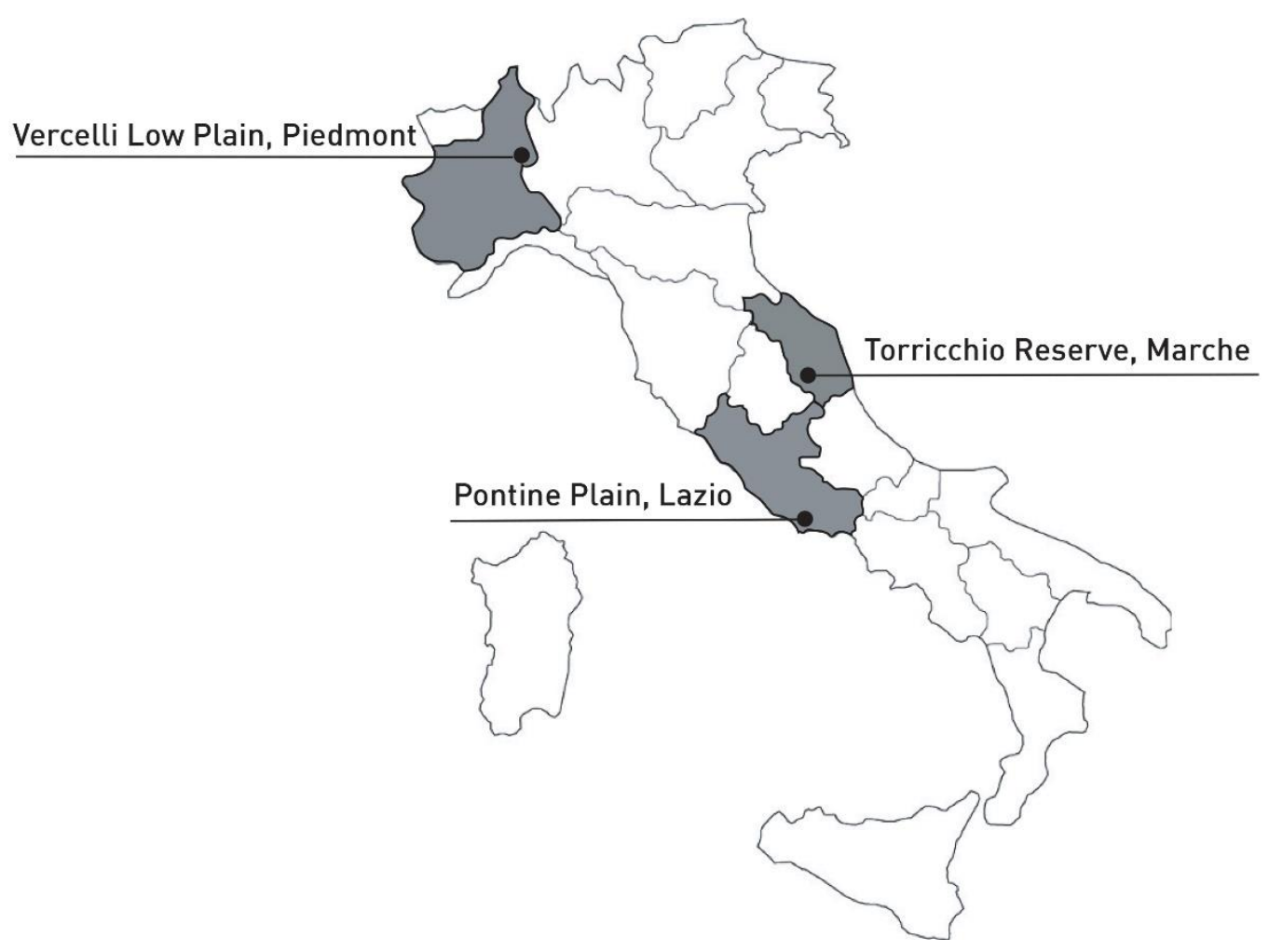

Figure 2. Overview of the regions and selected study cases.

Table 5. Main features of the study cases.

\begin{tabular}{|c|c|c|c|c|c|}
\hline Target Area/Region & Promoter/Coordinator & $\begin{array}{l}\text { Productive } \\
\text { Features }\end{array}$ & Policy Process & $\begin{array}{l}\text { Target Area } \\
\text { Extension }\end{array}$ & $\begin{array}{c}\text { CAP } \\
\text { Payments }\end{array}$ \\
\hline $\begin{array}{l}\text { Vercelli lowlands } \\
\text { plain, Piedmont }\end{array}$ & Province of Vercelli & $\begin{array}{l}\text { Submerged rise } \\
\text { cultivation }\end{array}$ & Wetland contract & 70,736 hectares & Pillar II \\
\hline Pontine Plain, Lazio & Province of Latina & Intensive farming & Pact for Biodiversity & 77,000 hectares & Pillar I, II \\
\hline $\begin{array}{c}\text { Torricchio Reserve, } \\
\text { Marche }\end{array}$ & $\begin{array}{l}\text { Università di } \\
\text { Camerino }\end{array}$ & Grazing & $\begin{array}{c}\text { Agri-environmental } \\
\text { Agreement }\end{array}$ & 1231 hectares & Pillar II \\
\hline
\end{tabular}

The following systematized methods were used to collect the data for each study case:

Study Case 1:

- $\quad$ Consultation of 7 territorial plans and programs (Hydrological Structure Plan; Po River Basin Management Plan; Piedmont Regional Territorial Plan; Piedmont Rural Development Programme; Regional Water Protection Plan; Provincial Coordination Plan; Regional Guidelines for River/Lake Contracts) and the management plans of 2 protected areas; 1 Memorandum of Understanding for the signing of the Wetland Contract; 5 progress reports (stakeholder analysis; scientific description of the area; Wetland Contract trend and oriented scenarios; participatory process development; Wetland Contract and Action Plan);

- $\quad$ Open ended and focused interviews to 1 manager of the Vercelli Province, and 1 manager of the Piedmont Region in charge for River/Lake/Wetland Contract coordination;

- $\quad$ Direct and participant observation to 5 Technical Secretariat meetings and 3 Focus groups [44].

- $\quad$ Study Case 2:

Consultation of 5 plans and programs (Regional Water Protection Plan, Lazio Rural Development Programme, Provincial Coordination Plan, Provincial Ecological Network, 
Environmental Restoration Program of Agro Pontino); 1 Memorandum of Understanding for the subscription of the Pact for Biodiversity;

- $\quad$ Open ended and focused interviews to 1 manager of the Latina Province, 1 manager of the Lazio Region in charge for agri-environmental measures coordination, and 1 director of Confagricoltura association;

- $\quad$ Direct and participant observation to 4 Technical Secretariat meetings [44].

- $\quad$ Study Case 3:

- Consultation of 2 plans and programs (Management Plan of the Torricchio Mountain Nature Reserve, Marche Rural Development Programme); 2 scientific papers on the topic; 1 Agri-Environmental Agreement, and 1 Land Stewardship Agreement;

- 1 focused interview to the delegate of the director for agri-environmental policies in the Torricchio Mountain Nature Reserve.

A key part of the work reported in each study case is related to stakeholders analysis (Tables 6 and 7). Table 6 reports the analysis of stakeholders' typology, resources, objectives and roles. Particular attention has been payed to the identification of roles, where, according to Dente's definition, the Promoter is the actor giving the first stimulus to the process, that can correspond to the process director, the one that has to pilot the process until the end; the allied has content and process objectives congruent to those of the promoter and brings its resources to the process partnership; the gatekeeper, because of the resources he controls, has the possibility to use its veto power and block the process [45], contributing to shaping a policy process of regional and/or national interest but with local consequences. Table 7 proposes a matrix revealing the complexity (within each cell and among different cells) of the area-based multi-level and multi-actor decision process at stake, due to heterogeneity of the interests and potential conflicts [45].

Table 6. Stakeholder analysis framework: Typology, Resources, Objectives, Roles.

\begin{tabular}{lcccc}
\hline Stakeholders & Typology & Resources & Objectives & Role \\
\hline Stakeholder 1 & Politician & Political & contents & Promoter \& Director (policy entrepreneur) \\
Stakeholder 2 & Administrators & Financial & contents & Gatekeeper \\
Stakeholder 3 & Administrators & Legal & process & Allied \\
Stakeholder 4 & Special Interest & Knowledge & contents & Allied \\
\hline
\end{tabular}

Table 7. Framing the policy process complexity.

\begin{tabular}{|c|c|c|c|c|c|}
\hline \multirow{2}{*}{ Dimension of the Interest } & \multicolumn{5}{|c|}{ Stakeholders Typology } \\
\hline & Politicians & Administrators & Experts & Special Interests & General Interests \\
\hline $\begin{array}{c}\text { National } \\
\text { Regional } \\
\text { Local }\end{array}$ & & & & & \\
\hline
\end{tabular}

The three study cases share multilevel governance schemes calling into question public-private partnerships and forms of agreement that allow to adopt a set of regulations in which criteria of public utility, economic return, social value and environmental sustainability equally take part in the search for effective solutions in an area-based approach. Those agreements, whose specificities will be detailed in the 'Results' paragraph, do not constitute a new planning act or a new decision-making level, but rather bring the specific strategies and competences of the stakeholders involved towards a governance process, respecting the specificities and autonomies, with a flexible updatable, inter-sectoral and inter-scalar approach. At the same time, they should not be understood as mere inter-institutional agreements aimed at sharing government objectives, but rather as a decision-making and operational process that makes up the environmental and socio-economic interests of a water system, implementing the superordinate provisions (territorial and sectorial) [46]. 
The first study case, led by the Province of Vercelli, in the Piedmont Region, relates to the Vercelli Lowlands plain Wetland Contract in the framework of the Interreg MED WETNET project.

The second study case regards the Pact for Biodiversity of the Pontine Plain, a multilevel governance tool aimed at improving the ecological management of agro-ecosystems. It falls under the EU Life Nature and Biodiversity funded project GREENCHANGE in the Pontine plain.

The third study case concerns the Agri-environmental Agreements of the Marche Region, promoted with the objective to engage and aggregate stakeholders around a specific environmental issue and joint territorial interventions for the conservation of biodiversity and the safeguard of the land and of the waters.

\section{Results}

\subsection{Regional Reward Criteria for Implementing the River/Wetland Contract Strategic Vision in Piedmont}

\subsubsection{General Features, Problems, and Open Issues}

The Vercelli Lowlands are a vast inland area of 70,736 hectares characterized by fresh-water paddy fields, constituting natural and landscape value as a whole. The area includes part of the western floodplain of the Sesia River and the northern floodplain of Dora Baltea and Po Rivers (Figure 3). It is also characterized by a complex system of irrigation canals and artificial waterways guaranteeing crop irrigation and rice cultivation. The area hosts 9 sites protected as Special Nature Reserves, 7 Sites of Community Importance (SCI), 6 Special Protection Areas (SPA) and 3 Natura 2000 sites; it falls within the administrative area of the Province of Vercelli (intermediate administrative body with coordination functions) and 28 municipalities.

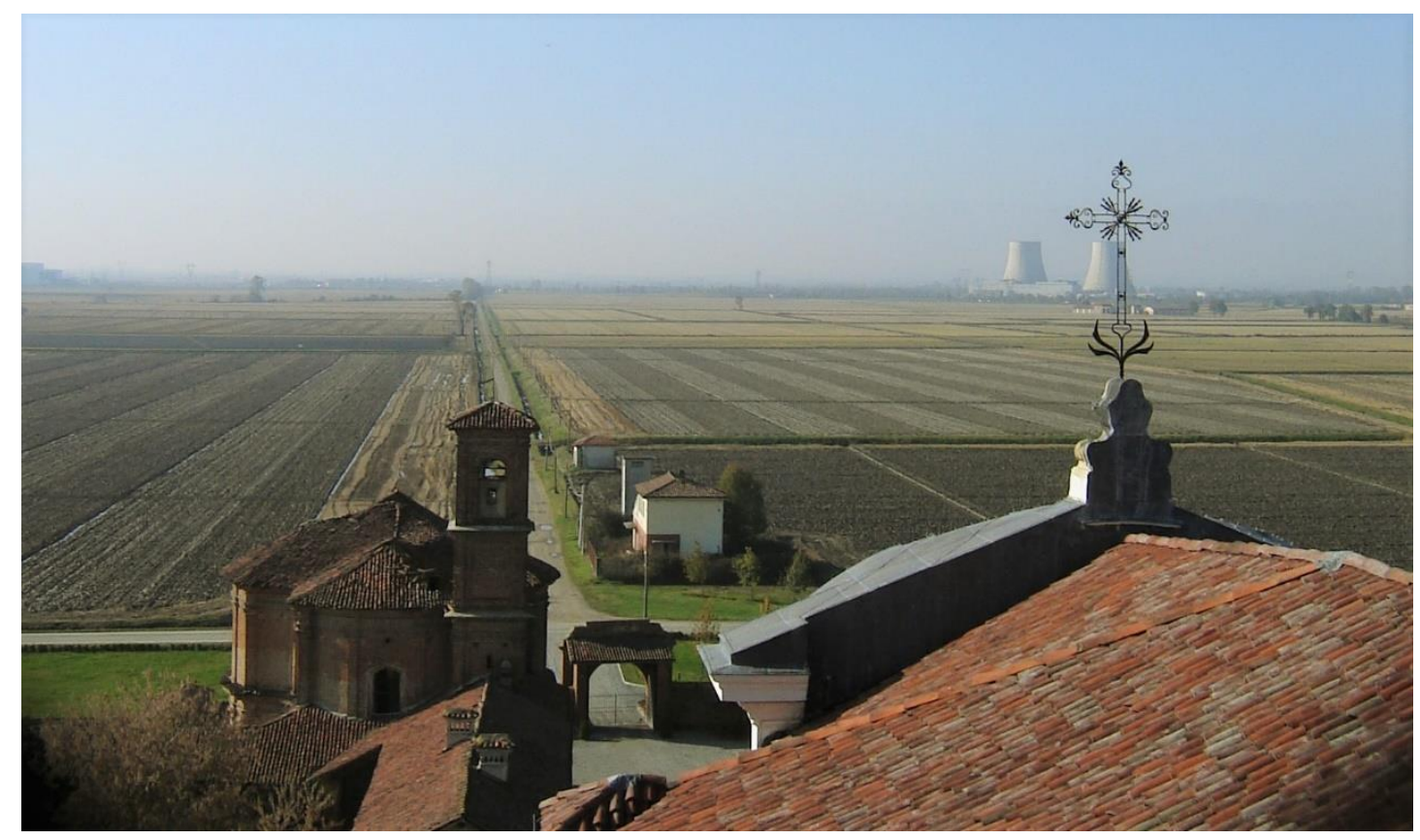

Figure 3. Paddy fields, Province of Vercelli, Piedmont Region (Author Stefano Magaudda).

The Vercelli Lowlands Wetland Contract was developed within Piedmont regional strategies for the integrated management of water resources in accordance with the Water Framework Directive (WFD). Through regional guidelines for implementing the River/Lake/Wetland Contracts, the Region institutionalizes the Contracts as a tool for implementing the Regional Water Protection Plan [47].

Formally the River/Wetland Contracts can be defined as voluntary commitments undertaken by various public and private entities in various capacities interested in the wetland system for the 
environmental restoration and socio-economic regeneration of water systems. The agreements are developed and formalized within a participatory and negotiated decision-making process leading to drafting of the programming act (Action Plan) with a medium-term duration. The latter compiles and integrates the various interests regarding a body of water, defining responsibilities and implementation tools for the governance and sustainable management of the water system. [48].

Initial funding for the development of this process came from the European Commission Interreg MED Program within the WETNET cooperation project which aims to define common priorities for wetland conservation in the Mediterranean area and encourage the adoption of River/Wetland Contracts for integrated governance.

\subsubsection{Governance Process Development}

The Province of Vercelli is in charge of area administration in all its aspects and promotes the focused process through its Urban and Regional Planning Department. The latter undertakes responsibilities in the fields of environmental protection, sustainable development, and regional planning, as it is in charge of the Provincial Coordination Plan (PCTP). With the Wetland Contract tool, it aims to implement a homogenous vision for the Province's sustainable development in accordance with the Ecological Network Plan (attached to the PTCP).

More specifically, the Province began the process of implementing the Wetland Contract, setting the scope of sustainably managing the Vercelli Lowlands and enhancing the ecological role of GI in paddy fields.

The process has developed consistently with superordinate planning tools, within which those concerning water management are of greater relevance. On the supraregional level, the Po River Basin Management Plan is the coordination tool of reference, aimed at implementing a coherent and sustainable water-protection policy, integrating the management and ecological aspects arising on the river-basin scale. On the regional level, the Piedmont Regional Water Protection Plan sets out the strategies for achieving the quality objectives for water bodies; it also mentions the possibility of activating negotiated tools such as River/Wetland Contracts.

To create a participatory process, the Province elicited 41 stakeholders with influence or interests in the area, of which $29 \%$ are public bodies, $20 \%$ are private for-profit entities, and $12 \%$ are private non-profit entities. Participatory meetings have then been attended by anywhere from 10 to 46 stakeholders (the Region and municipalities; instrumental bodies such as irrigation associations, protected-area managers, river authorities; farms and farmers' organizations; research institutes; environmental associations; educational institutions; trade associations; citizens). The Memorandum of Understanding $(\mathrm{MoU})$ preliminary to the final signing of the Contract (the procedure is required by the regional guidelines) has been signed by the Province, 28 municipalities, 3 park authorities, the Region, and the Po Basin Authority. The stakeholders subscribing to the Contract have been analyzed with reference to their type, available resources, objectives (either content—problem to face, solution to adopt-or process), and roles in the focused process (Table 8). Secondly, a matrix combining the dimension of territorial interest with the type of stakeholder was developed to measure the complexity of the policy process (Table 9). This data shows that towards the end the process increasingly became a policy act aimed at managing legal, administrative, and financial issues for the successful implementation of the Contract and its actions.

The Action Plan for the target Contract was structured around the strategic areas of governance, the environment, and social and economic development. The general objectives were: (i) to improve biodiversity, landscape, and water quality through new shared governance and planning schemes (e.g., Environmental Compensation Plan); and (ii) to mitigate the environmental impacts of rice paddies, strengthen their role as a habitat for wildlife, and improve their landscape quality. Much attention was focused on identifying detailed actions to implement GI on different levels. These include: the promotion of agreements to sustainably create and manage GI between municipalities and public and private entities, such as Land Stewardship Agreements (LSA); the adaptation of local (municipal) 
planning tools to the PTCP requirements in terms of ecological network, buffers and filter ecosystems in agricultural areas and wooded and green areas in urban context.

Table 8. Stakeholder analysis (main contributors): Type, resources, objectives, roles.

\begin{tabular}{ccccc}
\hline Stakeholder & Type & Resources & Objectives & Role \\
\hline Vercelli Province & Politician & Political/legal & process/contents & $\begin{array}{c}\text { Promoter \& Director } \\
\text { (policy entrepreneur) }\end{array}$ \\
Piedmont Region & Administrators & Political/legal/financial & process/contents & Ally \\
Po Basin Authority & General Interests & Legal & contents & Ally \\
Municipalities & Politician & Political/legal & contents & Ally \\
Park Authorities & Special Interests & Knowledge & contents & Ally \\
University & Experts & Knowledge & contents & Ally \\
Regional Agency for & Experts & Knowledge & process/contents & Ally \\
Environmental Protection & & & &
\end{tabular}

Table 9. Analysis of the policy process complexity, combining stakeholder type and the dimension of the interest at stake.

\begin{tabular}{|c|c|c|c|c|c|}
\hline \multirow{2}{*}{$\begin{array}{l}\text { Dimension of } \\
\text { the Interest }\end{array}$} & \multicolumn{5}{|c|}{ Stakeholder Type } \\
\hline & Politicians & Administrators & Experts & $\begin{array}{c}\text { Special } \\
\text { Interests }\end{array}$ & $\begin{array}{l}\text { General } \\
\text { Interests }\end{array}$ \\
\hline National & & & University & & $\begin{array}{l}\text { Po Basin } \\
\text { Authority }\end{array}$ \\
\hline Regional & & $\begin{array}{l}\text { Piedmont } \\
\text { Region }\end{array}$ & $\begin{array}{l}\text { Regional Agency for } \\
\text { Environmental Protection }\end{array}$ & & \\
\hline Local & $\begin{array}{l}\text { Province, } \\
\text { Municipalities }\end{array}$ & & & $\begin{array}{c}\text { Park } \\
\text { Authorities }\end{array}$ & \\
\hline
\end{tabular}

\subsubsection{Main Outcomes}

Some innovative elements for the governance of GI emerge from this study case. The first concerns the adopted tool, the Wetland Contract, which appears to be a flexible tool for embedding medium-term strategies and addressing multilevel, integrated responses for specific issues with a high impact such as GI. While the Wetland Contract does not constitute a new planning tool, it brings the specific strategies and skills of the stakeholders into the governance process, respecting specifics and autonomies with a flexible approach. At the same time, the tool is not merely an inter-institutional agreement aimed at sharing government objectives; rather, it can be considered a decision-making and operational process capable of creating and implementing a strategic vision in accordance with superordinate regulations [46].

The second element of interest concerns the structuring of the Contract's actors and their respective roles. The Region addresses, coordinates, and accompanies, also by defining the basic policies to construct and manage decision-making processes. At turn, the Province, as the body in charge of the environment, drafts and manages the Contracts and the participatory process. Finally, the municipalities act as collectors of local projects, interests and initiatives, conveying to the Province some local options. This structure seems to be applied in most of the River/Lake/Wetland Contracts in Piedmont, since it is also encouraged by the Region [48].

The last aspect is the successful connection of European policies to local context in an area-based approach. Besides integrating River/Wetland Contracts in its policies, the Piedmont Region has developed a reward mechanism for funding initiatives/projects/interventions included in River/Wetland Contracts. This mechanism consists of a specific score reserved for such actions in public calls for Regional Operational Programme (ROP)/RDP funding. In this way, the Region promotes the implementation of actions within a vision based on a wide-area scope potentially integrated with regional funding.

In reference to the types of reforms identified in Table 5, this study case addresses point 2.1, functional and procedural decision-making changes at the intergovernmental level, which also affect the local scale by introducing horizontal subsidiarity principles and by promoting the implementation 
and update of programming tools and plans, as specified at point 2.2; and point 3.1, concerning changes in funding procedures for a more efficient allocation of RDP funds in reference to the focused field.

\subsection{The Pact for Biodiversity of the Pontine Plain: Towards the Ecological Network in Agricultural Areas}

\subsubsection{General Features, Problems, and Open Issues}

The Pontine Plain is the result of the "Great Land Reclamation" of the 1920s, which profoundly changed the hydrography, topography, biodiversity, urbanization, economy, identity, and landscape of the area. This peculiar landscape is currently undergoing extensive transformation due to intensive agriculture, industrialization, and urban sprawl (Figure 4).

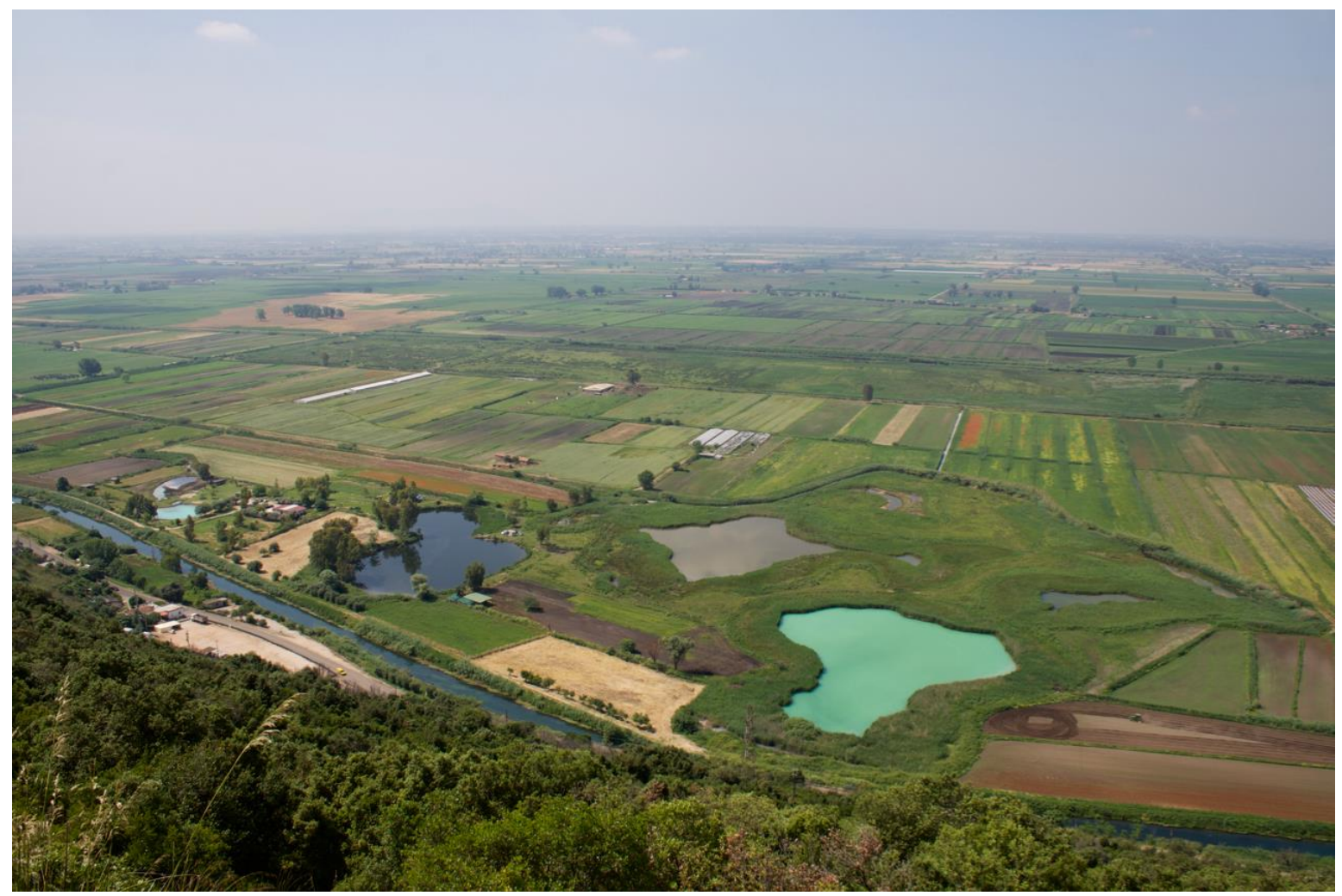

Figure 4. Pontine Plain, Gricilli area, Province of Latina, Lazio Region. (Author Giovanni Mastrobuoni).

Over the last 20 years, the Province of Latina has carried out a series of activities aimed at restoring the Pontine Plain by taking advantage of the potential connectivity of its green and blue infrastructure (windbreak strips, reclamation of canal banks and their buffer zones). Consistent with the Water Framework Directive (2000/60/EC) and Habitat Directive (1992/43/EEC), the Province developed the Ecological Network within the Provincial Coordination Plan (PTCP), and the Integrated Environmental Restoration Program of the Pontine Plain. This set of previous experiences committed the Province to a new initiative within the context of the EU-funded project LIFE GREENCHANGE, which aims to test intervention models for implementing these plans.

More specifically, GREENCHANGE intends to help halt the loss of biodiversity and enhance the ecological value of the plain by introducing the Pact for Biodiversity committed to the ecological management of agro-ecosystems through an integrated set of actions and tools. It works to systematize actions in agricultural areas and harmonize priorities, methods for intervention, and financing sources towards ecosystem preservation and restoration. To this aim, networking among individual farm-scale restoration actions has been spurred in order to achieve ecological continuity, even relying to the optimization of funding sources. 
The Pact is developed based on recognition of the agroecosystems' added values by maintaining certain natural elements within the agricultural pattern, even in terms of productivity and quality products. Awareness about the "services" provided by such agroecosystems supports the identification of best practices and the most adequate tools to maximize them. The pact's actions concern the development of scenarios to maintain the agricultural land through the lens of ecosystem services, the production of shared rules and guidelines for the environmental management of interventions, and the active involvement of farmers in the management through LSA.

\subsubsection{Governance Process Development}

As mentioned above, the Province of Latina was the promoter of the Pact for Biodiversity of the Pontine Plain and acted also as director of the process, taking responsibility for engaging the relevant stakeholders on both the regional and local levels. The Pact is designed as an open and permanent working table with the goal of encouraging stakeholders to share methods, tools, and practices to manage agricultural areas in order to achieve its objectives.

As shown in Table 10, the Pact involves an articulated set of stakeholders belonging to both the environmental and farming sectors who are interested for political, managerial, and production reasons. These are local and regional authorities (Rural Development Programmes' managing bodies), the Protected Area managing bodies, and farmers and their associations [49]. It is worth mentioning the key role of the Lazio Region as a gatekeeper of the process, since some of the Pact's achievements depend on the cooperation of regional bodies in enabling specific processes (see below for loans for the use of GI) and the successful integration of its actions and objectives with RDP funding.

Table 10. Subscribing stakeholder analysis: type, resources, objectives, roles.

\begin{tabular}{ccccc}
\hline Stakeholder & Type & Resources & Objectives & Role \\
\hline Province of Latina & Politician/Administrators & Political/legal & contents & $\begin{array}{c}\text { Promoter \& Director } \\
\text { (policy entrepreneur) } \\
\text { Gatekeeper }\end{array}$ \\
Lazio Region & Politician/Administrators & Political/legal/financial & process/contents & Ally \\
Land Reclamation & Special Interest & Legal & contents & Ally \\
Association & Politician/Administrators & Political/legal & contents & Ally \\
Municipalities & Special Interests & Knowledge & contents & Ally \\
Park authorities & Special Interests & Political & contents & Ally \\
Farmers associations & Experts & Knowledge & contents/process & \\
Research institutions & & & &
\end{tabular}

Participation of the listed stakeholders is necessary to establish the integrated objectives and measures of the Pact and to ease the collaborative implementation of such measures. The complexity of interests and issues emerges from Table 11.

Table 11. Analysis of the policy process complexity.

\begin{tabular}{|c|c|c|c|c|c|}
\hline \multirow{2}{*}{$\begin{array}{c}\text { Dimension of the } \\
\text { Tnterest }\end{array}$} & \multicolumn{5}{|c|}{ Stakeholder Type } \\
\hline & Politicians & Administrators & Experts & Special Interests & $\begin{array}{l}\text { General } \\
\text { Interests }\end{array}$ \\
\hline National & & & $\begin{array}{l}\text { Research } \\
\text { institutions }\end{array}$ & & \\
\hline Regional & & Lazio Region & & & \\
\hline Local & $\begin{array}{l}\text { Province of Latina, } \\
\text { Municipalities }\end{array}$ & & & $\begin{array}{c}\text { Park authorities, } \\
\text { Farmers associations, } \\
\text { Land Reclamation } \\
\text { Association }\end{array}$ & \\
\hline
\end{tabular}

The direct involvement of farmers in the implementation and management of the ecological network is a key issue. This has been promoted considering the essential role of EU funding for farmers and rural development, and is therefore based on the remuneration of the areas in the context of the CAP.

The Pact relates to financing opportunities offered by the CAP in two ways. With reference to funding under the First Pillar, the Pact develops tools to facilitate farmers' access to it, such as: 
(i) a catalogue containing the description of selected agricultural practices and their economic, productive, and environmental impacts in the short and long term; (ii) an information desk to support farmers during the funding application process; and (iii) an information technology tool to help farmers to plan sustainability and assess business efficiency in agronomic, economic, and ecological terms. The Pact acts as a learning environment for long-term management of rural areas (including productivity), also offering training for farmers about ecosystem services and related benefits on the farm business. It presents scenarios about the variation of ecosystem services and their potential impact on yield (quantity/quality/costs), while providing best practices for the proper management of agroecosystems (to maintain/improve ecosystem services).

Moreover, a specific mechanism is established by the Pact to enhance access to CAP funding. This mechanism is based on the possibility for farmers to fulfil the greening requirements on state-owned GI. Through loan-for-use contracts with the Region (owner and body in charge of managing windbreaks and canal banks), such areas become part of the farm dossier and are eligible for funding. The benefit farmers receive is twofold: besides CAP direct payments, the possibility of devoting areas outside of their productive land to greening. In this framework, LSA formalize farmers' commitments to the conservation and restoration of nature on their property and in state-owned areas whose management has been transferred to them.

With reference to the Second Pillar, the Pact works to improve the grant criteria for RDP funding in order to meet the objectives established in the Pact and the results achieved during its testing phase (GREENCHANGE project). Interaction with the Lazio Region will enable the identification of rewarding criteria to favor the allocation of funds to farms adhering to the Pact by signing LSA or carrying out interventions consistent with the measures of the Pact.

\subsubsection{Main Outcomes}

The Pact proves an innovative governance tool able to streamline regional complexity in an area-based, multilevel vision coordinating actors with specific skills and interests. On the one hand, the Pact prepares a selection of the regional-owned areas suitable for applying restoration measures as a knowledge base for implementing GI in the region. At the same time, the Pact concretely implements GI, by offering the support of regional authorities to farmers associations, thanks to availability of RDP funding and a mechanism for enhancing the capture of CAP direct funding. In this respect, this second study case embeds the type of reforms listed at point 2.1,2.2 and 3.1 of Table 5, by setting a multilevel governance tool focused on the agri-environmental field capable of implementing the existing tools (i.e., the Integrated Environmental Restoration Program of the Pontine Plain) and effectively integrating Pillar I and II funding for specific local needs.

The Pact approach allows for a tailor-made regional coordination consistent with the next CAP programming period, where the relevance of agri-environmental measures and the cooperative approach are expected to be reinforced.

\subsection{The Area-Based Agri-Environmental Agreements of the Marche Region}

\subsubsection{Context}

The third study case focuses on the Agri-Environmental Agreements (AEA) promoted by the Marche Region with the aim of fostering an integrated and area-based approach while implementing sustainable rural practices. According to the Marche RDP, an AEA is defined as a "set of commitments for farmers in a specific area, supported through a mix of RDP measures to achive specific environmental goals". Based on a territorial approach involving public and private actors, AEAs are aimed at implementing collective and coordinated actions to manage and improve the environment.

This study case focused on the type of AEA foreseen by the 2007-2013 RDP-financed for the first time in 2011-which targets the protection of biodiversity in Natura 2000 areas. It considers the area of the Torricchio Mountain Nature Reserve, which was established in 1974 and is owned by the University 
of Camerino (UNICAM), who is also in charge of its management with WWF patronage (Figure 5). The reserve extends for 500 hectares and targets the protection of priority habitat "6210 Semi-natural dry grasslands and shrubland facies on calcareous substrates (Festuco-Brometalia) (important orchid sites)". UNICAM, together with local mountain communities, has created a 3,000 hectare district corresponding to the surrounding "Valnerina, Montagna di Torricchio, Monti Fema e Cavallo" Special Protection Area (SPA), for a more effective pasture and ecological management.

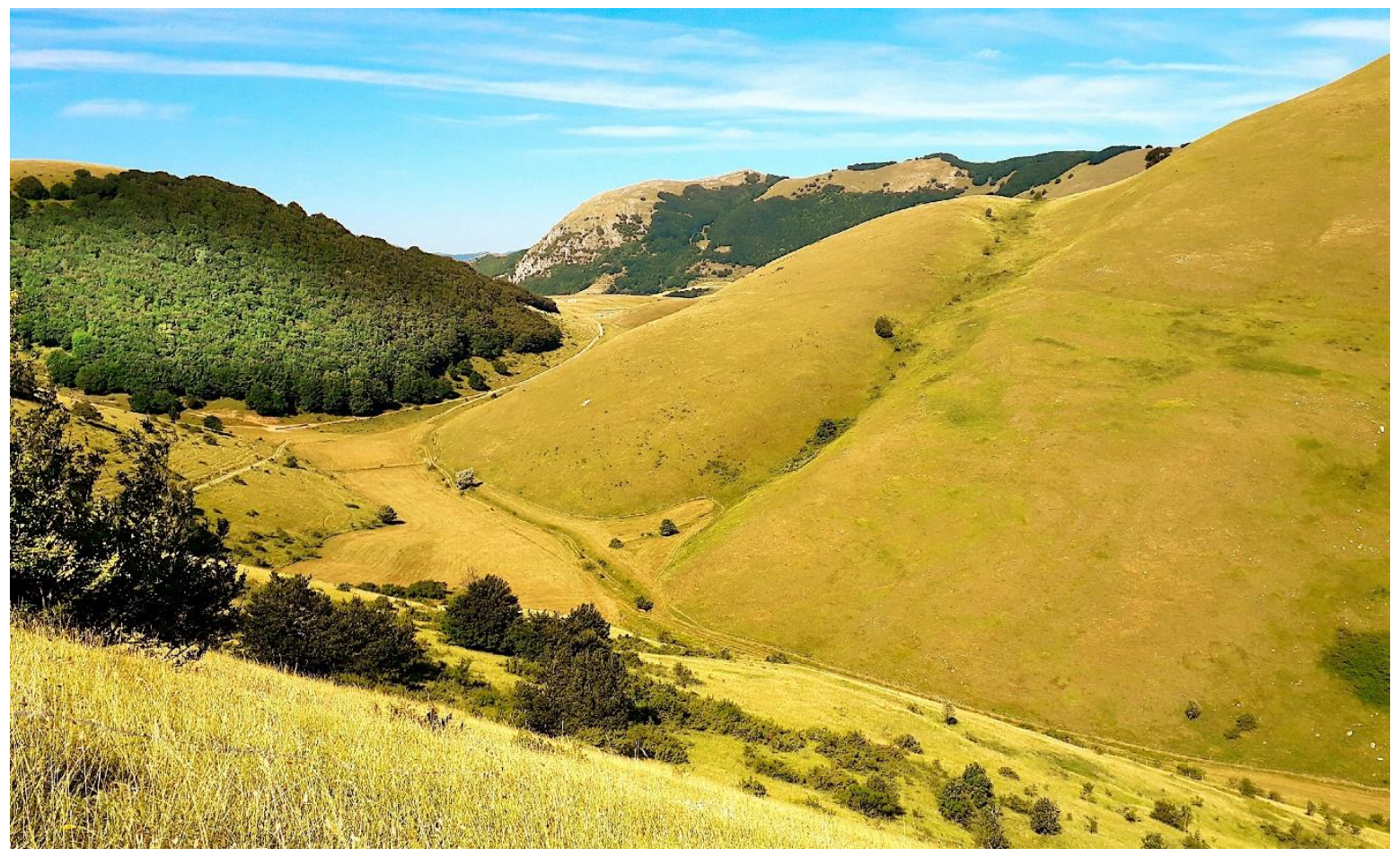

Figure 5. Torricchio Reserve, Province of Macerata, Marche Region (Author: Andrea Catorci).

\subsubsection{Process Development}

UNICAM, as an AEA promoter and coordinator, was in charge of facilitating the agreement's development, drafting the general project, coordinating the individual beneficiaries applying for funding, and reporting to management authorities about the implementation process. UNICAM initially had to establish a dialogue with the 40 livestock farms participating in the agreement-development process in order to overcome their skepticism about the Reserve management body. For this purpose, UNICAM not only coordinated an institutional board of local stakeholders (municipalities, farmers associations, business unions), but also formed a multidisciplinary team of scientists and appointed an agronomist facilitator in charge of dialoguing with every farm in the area.

The first step was to launch round tables with the farmers and their technicians in order to present RDP measures and funding opportunities, notably in reference to the protection of pasture-related habitats. Such workshops offered the opportunity to jointly define the objectives and conservation measures of the Natura 2000 and area management plans. The stakeholders involved in this process are listed in Table 12. 
Table 12. Participating stakeholder analysis: type, resources, objectives, roles.

\begin{tabular}{ccccc}
\hline Stakeholders & Type & Resources & Objectives & Role \\
\hline UNICAM/Reserve & Administrators & Legal/Knowledge & contents & $\begin{array}{c}\text { Promoter \& Director } \\
\text { (policy entrepreneur) } \\
\text { Manager }\end{array}$ \\
$\begin{array}{c}\text { Marche Region } \\
\text { Municipalities/Mountain }\end{array}$ & Administrators & Legal/financial & process/contents & Ally \\
Communities & Politician/Administrators & Political/Legal & contents & Ally \\
NGOs & Special Interests & Knowledge & contents & Ally \\
Farmers & Special interests & Knowledge & contents & Ally \\
Farmers Associations & Special Interests & Political/Knowledge & contents & \\
\hline
\end{tabular}

The AEA of the Torricchio Reserve aims to bring the mountain meadow up to a good state of conservation. The solutions to improve the habitat were drafted by the entire community via a participatory process that lasted about a year. Thirty-eight farmers were engaged in the process, and twenty-five signed the agreement. The governance process resulted in a Pasture Plan containing conservation measures and management regulations that are also binding for the farmers that have not endorsed the agreement (Table 13).

Table 13. Analysis of the policy process complexity.

\begin{tabular}{|c|c|c|c|c|c|}
\hline \multirow{2}{*}{$\begin{array}{l}\text { Dimension of } \\
\text { the Interest }\end{array}$} & \multicolumn{5}{|c|}{ Stakeholder type } \\
\hline & Politicians & Administrators & Experts & $\begin{array}{l}\text { Special } \\
\text { Interests }\end{array}$ & $\begin{array}{l}\text { General } \\
\text { Interests }\end{array}$ \\
\hline National & & & & & NGOs \\
\hline Regional & & Marche Region & UNICAM & $\begin{array}{c}\text { Farmers } \\
\text { associations }\end{array}$ & \\
\hline Local & $\begin{array}{l}\text { Municipalities/Mountain } \\
\text { Communities }\end{array}$ & $\begin{array}{l}\text { UNICAM/Reserve } \\
\text { Manager }\end{array}$ & & Farmers & \\
\hline
\end{tabular}

After the approval of the AEA, the Region launched a three-year call for funding addressed at the participating farmers who, in order to obtain funding, not only have to respect the agreement, but also have to co-operate to manage the collective goods. The role of UNICAM was pivotal in the discussion with the Region, especially when addressing RDP calls for measures and interventions. The loss of earnings due to the meadows' maintenance as well as experimental interventions for limiting invasive species were supported by regional funds through a system of mobile fences. In three years, $€ 600,000$ have been spent from the RDP for funding applications presented by agronomists, who had previously received training about the specific instrument.

\subsubsection{Main Outcomes}

In Italy, the Marche is undoubtedly the region that experimented and promoted a collective partnership approach within the RDP, even with training and in-depth information sessions for farmers. The AEAs were already developed in the 2007-2013 programming period and were further strengthened in the 2014-2020 one [12]. The main feature of this study case is the choice made by the Marche Region to allocate a significant share of the RDP resources for agricultural communities and businesses that implement and sign the AEAs, addressing in such way point 3.1 of Table 5 (funding reforms under intergovernmental relations).

In conclusion, AEAs innovated the relationships among the Reserve manager, farmers, and other stakeholders, setting the ground for the development of regional joint initiatives, allowing for further development of LSAs to manage and maintain common goods.

\section{Discussion and Conclusions}

Within the targeted study cases, the area-based experiences, whether or not depending on administrative boundaries, have demonstrated the effectiveness of governance practices based on both a large-scale vision and strong public leadership. The administrations involved successfully developed a comprehensive strategy for the restoration and enhancement of the territory by considering the 
different environmental and landscape components as part of a single object of intervention. A main feature to all the experiences is the adoption of voluntary agreements. Regardless of their name, these "Pacts" are currently used as governance tools dealing with environmental protection, biodiversity, climate change, ecosystem services, land use management and sustainable development in rural areas.

The three study cases highlight the capacity to overcome conflicts between sectoral and institutional skill areas thanks to a collaborative and strategic approach, which is appropriate for the spatial context and planning goals [50], and not just for matters of habitat conservation.

In addition, the identification of a promoter in charge of coordinating the collaborative governance tools on the territorial scale has shown significant effectiveness. This organization has a key role in defining, managing, and monitoring the Pact. Moreover, it has to bring local needs and issues to the negotiating table with the State/Region, managing the allocation of EU funds. The study cases have demonstrated that "intermediate bodies" between the upper and the lower administrative level best suit in managing collaborative governance since they combine regional strategy with direct dialogue with local actors. The study cases therefore stress that effectiveness of collaborative tools in reference to GI implementation is closely connected to the promoters' capacity to negotiate and orient regional programmes' measures and funds.

Tools such as these Pacts do not add another planning level to a context already characterized by multiple overlapping regulatory tools. On the contrary, flexibility and administrative simplification allow for greater adaptability to local contexts and EU funding opportunities.

Another successful aspect to highlight is the participatory approach in defining the practices to be adopted, likely to increase the engagement of farmers and their awareness of environmental issues [51].

The study cases of the Pact for Biodiversity and the Torricchio Reserve AEA witnessed the solid involvement of farmers in decision-making processes, and in both cases a cooperative approach was promoted for managing common goods and natural resources. The great relevance given to the social aspect in terms of participation and appreciation of the involved communities are viewed as preconditions for maintaining and correctly managing GI [52].

The European Commission promotes these integrative approaches to strengthen synergies resulting from commitments jointly undertaken by a group of farmers, thereby multiplying the environmental and climate benefits [53]. The advantages of applying a collective approach to agriculture are widely documented and concern not only the interventions' effectiveness, but especially the capacity to encourage technical, organizational and social innovations that allow new knowledge networks to be built [49].

Considering the key role of the agricultural sector in providing GI, the CAP's radical reform is certainly expected to set ambitious objectives for the environment and the fight against climate change. On the one hand, greening would become an additional element of enhanced conditionality, and the introduction of eco-schemes would substantially move some agri-environmental issues from the Pillar II to the Pillar I, with the aim of encouraging sustainable practices in traditional and intensive agricultural production systems. On the other hand, by doubling some environmental measures between eco-schemes (Pillar I) and RDP (Pillar II), a strategic vision in planning and management of these measures at the regional scale might be missing. In the preliminary phase of negotiating of the national "CAP strategic plan" (in state/regional conferences), the challenge has been to make environmental and climatic measures consistent, since they are still on separate tracks. The first drafts of the "CAP strategic plans" lack a territorial vision that, in turn, could lead to the loss of the synergic and cumulative effect of some ecological interventions and measures. It is clear that in Italy, characterized by diverse agricultural realities (type of farms and territorial features), all regions, through the RDP measures (such as the "cooperation" measure), will be charged with ensuring the effectiveness of interventions in a territorial framework. On the one hand, planning tools should be tied by an overall coherence with respect to structural and strategic objectives rather than to rigid 
compliance rules. On the other hand, governance schemes in decision-making processes should introduce public partnerships and public-private agreements.

Finally, convergence between different disciplines and institutional frameworks can be attained by bridging ecological connectivity with greening and agri-environmental measures provided by the CAP. However, such crucial issue can be settled only through policy measures countering land fragmentation at different scales in tune with planning tools likely to accommodate ecological corridors and green networks. These actions should be framed on a regional scale and through cooperative approaches.

Future research could analyze the most suitable tools to foster and organize the relationships among key stakeholders according to the collaborative governance tools described above.

Author Contributions: All authors have read and agreed to the published version of the manuscript. Issues and contents of this article were largely discussed and shared by the Authors, who have jointly written all Sections, except for Section 2, written by A.L.P. and R.D.A., and Section 4, written by S.M. (Stefano Magaudda) and S.M. (Serena Muccitelli).

Funding: This research received no external funding.

Acknowledgments: The Authors are grateful to Andrea Catorci of UNICAM; Veronica Platinetti of the Vercelli Province and Carlotta Sigismondi of the Research Institute Poliedra for the interviews and the materials made available. The authors would like to thank the reviewers for their careful, constructive and insightful comments

Conflicts of Interest: The authors declare no conflict of interest

\section{References}

1. European Commission. The Fifth EC Environmental Action Programme; European Commission: Brussels, Belgium, 1992.

2. European Environmental Agency. Environment in the European Union at the Turn of the Century; EEA: Copenhagen, Denmark, 1999; ISBN 92-828-6775-7.

3. European Commission. White Paper on Environmental Liability COM (2000) 66 Final 9 February 2000; European Commission: Brussels, Belgium, 2000.

4. Kingston, S. (Ed.) European Perspectives on Environmental Law and Governance; Routledge: New York, NY, USA, 2013.

5. European Commission. Communication to the European Parliament, the Council, the European Economic and Social Committee and the Committee of the Regions: Green Infrastructure (GI)_Enhancing Europe's Natural Capital; European Commission: Brussels, Belgium, 2013.

6. European Commission. The EU Guidance Document on Integrating Ecosystems and Their Services in Decision-making; European Commission: Brussels, Belgium, 2013.

7. European Commission. EU Guidance Document on a Strategic Framework for Further Supporting the Deployment of EU-Level Green and Blue Infrastructure SWD, 193 Final, 2019; European Commission: Brussels, Belgium, 2019.

8. Millennium Ecosystem Assessment. Ecosystems and Human Well-Being: Synthesis; Island Press: Washington, DC, USA, 2005.

9. TEEB. The Economics of Ecosystems and Biodiversity. In The Economics of Ecosystems and Biodiversity-An Interim Report; European Commission: Brussels, Belgium, 2008.

10. Allen, B.; Keenleyside, C.; Menadue, H. Fit for the Environment: Principles and Environmental Priorities for the 2014-2020 Rural Development Programmes; Report Produced for the RSPB; Institute for European Environmental Policy: London, UK, 2012; Available online: http://minisites.ieep.eu/assets/985/IEEP_2012_ Fit_for_the_environment.pdf (accessed on 28 October 2019).

11. Roggero, P.P.; Todari, M.; Seddaiu, G. Agroecologia e politiche agroambientali. Agriregionieuropa 2006, 2, 35-39.

12. Vanni, F.; Cisilino, F.; Fiorani, F. L'esperienza degli Accordi Agroambientali d'Area nelle Marche. RRN Mag. 190 2011, 60, 58-59. (In Italian)

13. EC. Our Life Insurance, Our Natural Capital: An EU Biodiversity Strategy to 2020; COM, 2011, 244 Final; European Commission: Brussels, Belgium, 2011.

14. De Filippis, F. (Ed.) La Nuova PAC 2014-2020; Quaderni del Gruppo: Rome, Italy, 2013. (In Italian) 
15. Fabiani, G. Letture Territoriali Dello Sviluppo Agricolo; Franco Angeli: Milan, Italy, 1991. (In Italian)

16. Sotte, F. Scenari evolutivi del concetto di ruralità. Proposte e Ricerche 2013, 71, 122-144. (In Italian)

17. Esposti, R.; Sotte, F. Le Dinamiche Del Rurale. Letture Del Caso Italiano; Franco Angeli: Milan, Italy, 2001. (In Italian)

18. European Community. Single European Act; Title VII, art. 130 R; European Commission: Brussels, Belgium, 1987.

19. European Commission. Communication from the Commission to the European Parliament and the Council on "The Future of the Rural World"-COM(88) 501 Final 1988; European Commission: Brussels, Belgium, 1989.

20. Anania, G. (Ed.) Policy Vision for Sustainable Rural Economies in an Enlarged Europe; Studies on Spatial Development; Akademie für Raumentwicklung in der Leibniz-Gemeinschaft: Hannover, Germany, 2003; Volume 4.

21. European Commission. EU Commission-COM Document (1997) Agenda 2000_For a Stronger and Wider Union; Document Drawn up on the Basis of COM (97) 2000 Final, 13 July 1997. Bulletin of the European Union, Supplement 5/97; European Commission: Brussels, Belgium, 1997.

22. De Filippis, F. (Ed.) Oltre il 2013. Il Futuro Delle Politiche Dell'unione Europea Per L'agricoltura e le Aree Rurali; Quaderni del Gruppo: Rome, Italy, 2013. (In Italian)

23. Boschetto, R.G. Il greening nella PAC quale strumento innovativo per una gestione conservativa del suolo. Reticula 2014, 7, 36-40. (In Italian)

24. Campli, M.; Pascale, A. Sdoppiare La Pac. 2018. Available online: http://www.alfonsopascale.it/index.php/ sdoppiare-la-pac/\# (accessed on 22 December 2019).

25. Pupo d'Andrea, M.R. Finestra sulla Pac n. 31. Agriregionieuropa 2016, 44, 31. Available online: https: //agriregionieuropa.univpm.it/it/content/article/31/44/finestra-sulla-pac-n-31 (accessed on 29 November 2019).

26. Cagliero, R.; Monteleone, A.; Varia, F. Le criticità di attuazione dei Psr 2014-20 attraverso le Postazioni regionali della Rete Rurale Nazionale. Agriregionieuropa 2018, 52. Available online: https:/agriregionieuropa. univpm.it/it/content/article/31/52/le-criticita-di-attuazione-dei-psr-2014-20-attraverso-le-postazioni-regionali (accessed on 29 November 2019).

27. European Commission. DG Agriculture and Rural Development: The Post-2020 Common Agricultural Policy: Environmental Benefits and Simplifications. 2019. Available online: ec.europa.eu/info/sites/info/ files/food-farming-fisheries/key_policies/documents/cap-post-2020-environ-benefits-simplification_en.pdf (accessed on 6 December 2019).

28. Saraceno, E. Le molte ambiguità delle politiche rurali dell'UE: Come affrontarle dopo il 2020? Agriregionieuropa 2017, 50, 31-35. (In Italian)

29. European Environment Agency. Urban Sprawl in Europe-The Ignored Challenge. EEA Report n. 10/2006; European Environment Agency: Copenhagen, Denmark, 2006.

30. Council Directive 92/43/EEC of 21 May 1992 on the Conservation of Natural Habitats and of Wild Fauna and Flora. Available online: https://eur-lex.europa.eu/LexUriServ/LexUriServ.do?uri=OJ:L:1992:206:0007:0050: EN:PDF (accessed on 12 December 2019).

31. United Nations. Convention on Biological Diversity. 1992. Available online: https://www.cbd.int/doc/legal/ cbd-en.pdf (accessed on 26 November 2019).

32. SCBD. Decision Adopted by the Conference of the Parties to the Convention on Biological Diversity at Its Tenth Meeting. X/2. The Strategic Plan for Biodiversity 2011-2020 and the Aichi Biodiversity Targets; SCBD: South Jakarta, Indonesia, 2010; Available online: https://www.cbd.int/doc/decisions/cop-10/cop-10-dec-02-en.pdf (accessed on 26 November 2019).

33. D'Ascanio, R.; Palazzo, A.L. Molteplicità Territoriali: Il periurbano tiburtino. Spec. Issue Urban. Inf. 2018, 272, 651-654. (In Italian)

34. Sandstrom, U.G. Green Infrastructure Planning in Urban Sweden. Plan. Pract. Res. 2002, 17, $373-385$. [CrossRef]

35. Davies, C.; McGloin, C.; MacFarlane, R.; Roe, M. Green Infrastructure Planning Guide Project: Final Report. Annfield Plain NECF 2006. [CrossRef]

36. Benedict, M.A.; McMahon, E.T. Green infrastructure: Smart conservation for the 21st century. Renew. Resour. J. 2002, 20, 12-17.

37. Benedict, M.A.; McMahon, E.T. Green Infrastructure: Linking Landscapes and Communities; Island Press: Washington, DC, USA, 2006. 
38. Clergeau, P.; Blanc, N. (Eds.) Trames Vertes Urbaines. De la Recherche Scientifique au Projet Urbain; Le Moniteur Editions: Paris, France, 2013.

39. Andreucci, M.B. Progettare Green Infrastructure. Tecnologie, Valorie Strumenti Per la Resilienza Urbana; Wolters Kluwer: Milano, Italia, 2017. (In Italian)

40. Lafortezza, R.; Davies, C.; Sanesi, G.; Konijnendijk, C.C. Green Infrastructure as a tool to support spatial planning in European urban regions. For. Biogeosci. For. 2013, 6, 102-108. [CrossRef]

41. Grădinaru, S.R.; Hersperger, A.M. Green infrastructure in strategic spatial plans: Evidence from European urban regions. Urban For. Urban Green. 2019, 40, 17-28. [CrossRef]

42. Hansen, R.; Pauleit, S. From multifunctionality to multiple ecosystem services? A conceptual framework for multifunctionality in green infrastructure planning for urban areas. Ambio 2014, 43, 516-529. [CrossRef] [PubMed]

43. Dente, B.; Kjellberg, F. (Eds.) The Dynamics of Institutional Change. Local Government Reorganization in Western Democracies; Sage: London, UK, 1988; p. 191.

44. Yin, R.K. Case Study Research. Design and Methods; Sage: Thousand Oaks, CA, USA, 1994.

45. Dente, B. Le Decisioni Di Policy; Il Mulino: Bologna, Italy, 2011. (In Italian)

46. Ministero dell' Ambiente, Codice dell'Ambiente, D.Lgs 152/2006 (mod. 2016) art.68-bis. Available online: https://www.gazzettaufficiale.it/dettaglio/codici/materiaAmbientale. (accessed on 12 December 2019).

47. Ires Piemonte. PI Contratti di Fiume e di Lago in Piemonte. Politiche per la Tutela e il Mantenimento Della Risorsa Acqua; Rapporto di Ricerca; Centro Stampa Regione Piemonte: Turin, Italy, January 2012; Available online: www.ires.piemonte.it/pdf/Rapporto-Contratti-fiume-di-lago-Piemonte.pdf (accessed on 6 November 2019).

48. Gusmaroli, G.; Dodaro, G.; Schipani, I.; Perin, C.; Alberti, F.; Magaudda, S. Wetland Contracts: Voluntary-based agreements for the sustainable governance of Mediterranean protected wetlands. In Proceeding of the 2nd Euro Mediterrenean Conference for Environmental Integration, Sousse, Tunisia, 10-13 October 2019; Springer Nature: Berlin/Heidelberg, Germany, 2019. (In Italian)

49. Magaudda, S.; Muccitelli, S.; Pozzi, C. La governance ambientale dell'Agro Pontino: Dalla rete ecologica ai contratti di fiume. Reticula 2019, 22, 49-59. (In Italian)

50. Ahern, J. Green infrastructure for cities: The spatial dimension. In Cities of the Future Towards Integrated Sustainable Water and Landscape Management; Novotny, V., Brown, P., Eds.; IWA Publishing: London, UK, 2007; pp. 267-283.

51. Chiodo, E.; Vanni, F. La gestione collettiva delle misure agro-ambientali: Oltre le esperienze pilota? Agriregionieuropa. 2014, 36. Available online: https://agriregionieuropa.univpm.it/it/content/article/31/36/lagestione-collettiva-delle-misure-agro-ambientali-oltre-le-esperienze-pilota (accessed on 6 November 2019).

52. Malcevschi, S. Infrastrutture verdi e buone pratiche. Valutazione Ambient. 2013, 24, 21-23. (In Italian)

53. European Commission. Regulation of the European Parliament and of the Council No 1305/2013 of 17 December 2013 on Support for Rural Development by the European Agricultural Fund for Rural Development (EAFRD) and Repealing Council Regulation (EC) No 1698/2005; European Commission: Brussels, Belgium, 2013.

(C) 2020 by the authors. Licensee MDPI, Basel, Switzerland. This article is an open access article distributed under the terms and conditions of the Creative Commons Attribution (CC BY) license (http://creativecommons.org/licenses/by/4.0/). 